\title{
GūrJura and Gaupa.
}

I am delighted to see from Dr. Hoernle's paper in the Journal for October (just received) that the view of Indian history which I was, I believe, the first to put forward, is at last coming to its own. When I was editing for the late Sir J. M. Campbell, in 1892-4, the late Pandit Bhagwanlal Indraji's History of Gujarat, I was led to investigate the history of the name of that province. The views which I then formed were published in a summary form in the historical section of the Bombay Government's General Administration Report for the year 1892-3, and, being buried in a blue book, naturally attracted no attention. They were stated with greater fulness in vol. i, pt. 1 , of the Bombay Gazetteer, especially in Appendix 3 of that volume, which, however, seems to be very little known, even to professed students of early Indian history. They were restated with corrections in a revised version of my summary of 1892-3, which I contributed to the Bombay Government's General Administration Report of 1901-2. I claim to have been the first to establish the existence of a Great Gūrjara empire, and to suggest the Gürjara origin of some of the greatest Rajput clans, though to Mr. D. R. Bhandarkar belongs the credit of showing that the Gūrjara emperors are to be identified with the line of Bhoja of Kanauj. Dr. Hoernle will find, in the above quoted volume of the Bombay Gazetteer, one or two references to the Gürjaras which he has overlooked in making his own collections.

One word regarding the 'preceptorship' of Krishṇa II. The phrase quoted by Dr. Hoernle seems to me clearly to mean that the Rāshtrakūta king humbled the Gaudas. It is too often assumed that in the tenth century and earlier the name Gauda means Bengal. I think, however, that this is a mistake which is responsible for much misreading of Indian history. It was, I think, Professor R. G. Bhandarkar who first expressed doubts on the point, and suggested that Gauda meant Gonda in Oudh. The key to the riddle is to be found in Alberuni's notes on the "Völkertafel" of 
Varāhamihira (Sachau's Alberuni's India, i, 300), which informs us that Guḍa = Tänēshar. This explains why the Sārasvat Brahmans of the holy Sarasvati are the Gaudas par excellence, and why Gauda and Vanga are mentioned separately in the Baroda Grant of 812 A.D. The Gaudas whom Krishña II 'humbled' or 'schooled' were therefore the rulers of 'Hindustan' in the narrower sense, or in other words the Gürjaras themselves.

A. M. T. JACKson, T.C.S.

Belgaum, Nov. 7th, 1904.

The Graco-Indian Kings Strato I Soter anl Strato II Philopator.

In Mr. Vincent Smith's recently published “ Early History of India" - a most admirable summary of the results obtained in recent years by the workers in the various fields of Indian archæology-there occurs a passage bearing on the relationship of the two Stratos which seems to need some further explanation.

The passage in question occurs on p. 201 , and is as follows:

"Strato I, a Greek king of Kābul and the Panjāb, who was to some extent contemporary with Heliocles, seems to. have been succeeded by Strato II, probably his grandson; who, again, apparently, was displaced at Taxila by the Saka satraps. The satraps of Mathurā were closely connected with those of Taxila, and belong to the same period, a little before and after 100 B.c."

At the end of a note on this passage, Mr. Vincent Smith is kind enough to say "Mr. Rapson's numismatic researches are expected to throw more light on these matters." This has reference, no doubt, to certain views, concerning the relationship of the two Stratos and their place in the history of the Groco-Indian period, which I communicated orally to Mr. Vincent Smith some months ago, and which I hope soon to publish in the Numismatic Chronicle. In the meantime, it may help to explain the passage quoted above, if 